\title{
The Welfare Effects of Pension Reforms in an Aging Economy
}

\author{
Yuan-Ho Hsu \\ Department of Economics/Graduate Institute of Political Economy, National Cheng Kung University, Tainan City, Taiwan \\ Email: yhhsu@mail.ncku.edu.tw
}

How to cite this paper: Hsu, Y.-H. (2017) The Welfare Effects of Pension Reforms in an Aging Economy. American Journal of Industrial and Business Management, 7, 652-670.

https://doi.org/10.4236/ajibm.2017.75049

Received: March 28, 2017

Accepted: May 22, 2017

Published: May 25, 2017

Copyright $\odot 2017$ by authors and Scientific Research Publishing Inc. This work is licensed under the Creative Commons Attribution International License (CC BY 4.0).

http://creativecommons.org/licenses/by/4.0/

(c) (i) Open Access

\begin{abstract}
This paper develops a multigenerational overlapping (OLG) model to investigate the welfare effects of pension reforms in an aging economy. Given the declining trend in the proportion of young people to the old aged, it is feared that existing pay-as-you-go pension system may not be sustainable and it necessitates higher tax or premium contributions to maintain the sustainability of the fiscal and pension system. This paper investigates the effects of four reform programs aiming to enhance the sustainability of the pension system. The programs are: (a) an increase in pension contribution, (b) a reduction in pension benefit, (c) an extension of mandatory retirement age, and (d) a combination of program (b) and (c). Policy simulation results from this paper indicate that extending mandatory retirement age harms only little of the current generations' lifetime utility whereas it gradually improves future generations' life time utility. On the contrary, increase in pension contribution reduces lifetime utility of the current generation without benefitting future generation. Alternately increase in contribution ratio improves future GDP growth whereas reducing replacement ratio cannot. Finally, an increase in pension contribution worsens government budgetary condition whereas reducing replacement ratio does not.
\end{abstract}

\section{Keywords}

Population Aging, Pension Reform, Overlapping Generation, CGE Model

\section{Introduction}

Population aging represents the phenomena of shifting age distribution of a society's population toward older ages. Population aging has become one of the most significant demographic phenomena in many industrialized countries in the recent decades. However, some newly developed countries and regions, such as Korea and Taiwan whose fertility rate had declined in the past decades, have 
also exposed to the challenges resulting from population aging.

Population aging has many important socio-economic and health consequences. It calls for the needs to cope with problems and challenges resulting from the increasing share of the elderly in the society. The increase in the retirees to working-age population ratio in the aging economies has leaded to fervent social and political concerns on the sustainability of the current social support and social security systems. The increasing aged population also putts great pressure to bear on the national healthcare systems. Increasing proportion of aged population is likely to increase the prevalence of disability, frailty, and old age related noncommunicable chronic diseases. These demographic and public health developments also challenge the sufficiency of current public healthcare system. Moreover, population aging and shrinking labor force may slow down economic growth and reduce government tax base. Therefore, many people fear that the demographic bomb of population aging would degrade current economic life and increase the burdens of future generations to meet the commitments to the ever-increasing retired workers.

This paper develops an Auerbach and Kotlikoff [1] type general equilibrium overlapping generation (OLG) model to study the effect of population aging on the macroeconomy. Main interest of this paper is to investigate the impact of population aging on economic growth and national savings, and the welfare effect of pension reform in the aging economy. Taiwan has phased into aging economy in 1994. The official population projection in Taiwan predicts that Taiwan will become an aged economy in 2018 and super-aged economy in 2026. This paper uses Taiwan as object of investigation to explore the welfare effect of pension reforms.

The aging demographic transition is the result of increasing life expectancy and decreasing fertility. Figure 1 illustrated the historical statistics and projected data for both crude birth rate and crude death rate for Taiwan, dated 1974 to 2061. The crude birth rate in Taiwan has shown a downward sliding trend since the 1970's, except for some minor bumps in the years of dragon. The crude death rate has been increased from 4.91 in 1974 to 5.68 in 2000 and 7.33 in 2016. As long as the crude birth rate is still higher than the crude death rate, total population can still keep growing. However, once the gap between these gaps reversed, total population starts declining. The medium variant population projection made by the National Development Council in Taiwan predicts that both rates will cross each other around year 2022 (Figure 1). Given this demographic transition, the size of working age population has increased with a decreasing rate. As a result, the size of working age population will reach its summit in 2017. Even though the number of working age population has started declining, total population will keep growing as long as the sum of the crude birth rate and net immigration rate is still higher than the crude death rate. Once the injection of new population cannot compensate for the deceased population, total population starts declining. The expected timing for aggregate population to decline is in year 2025 approximately (Figure 2). The size of old age population, defined as 


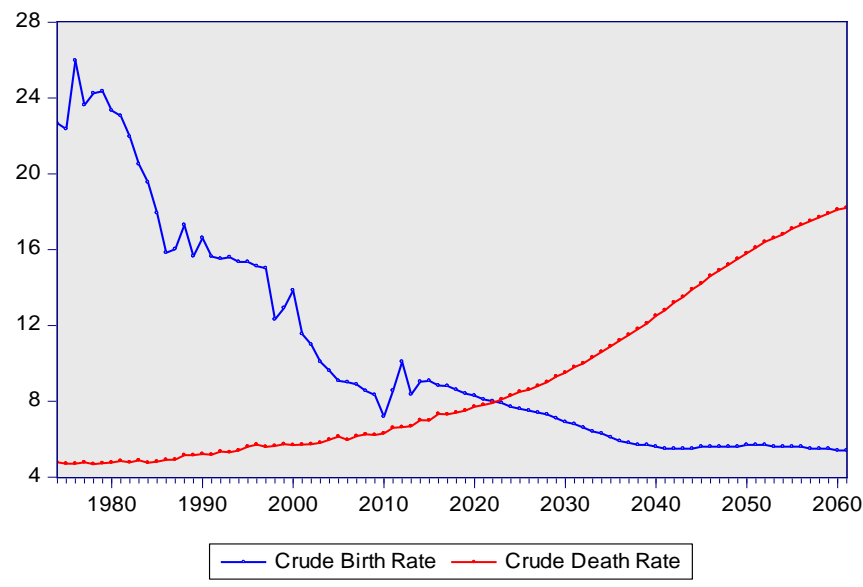

Figure 1. Demographic transition and its components, 1974-2061 (units: \%o). Source: Ministry of Interior (Taiwan) for data before 2016; National Development Council (Taiwan) for population projections beyond $2016^{1}$.
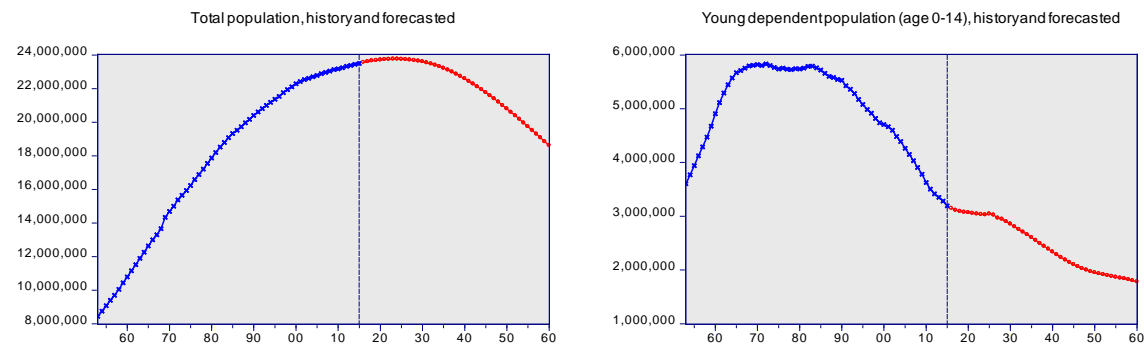

Working age population (age 15-64), historyand forecasted
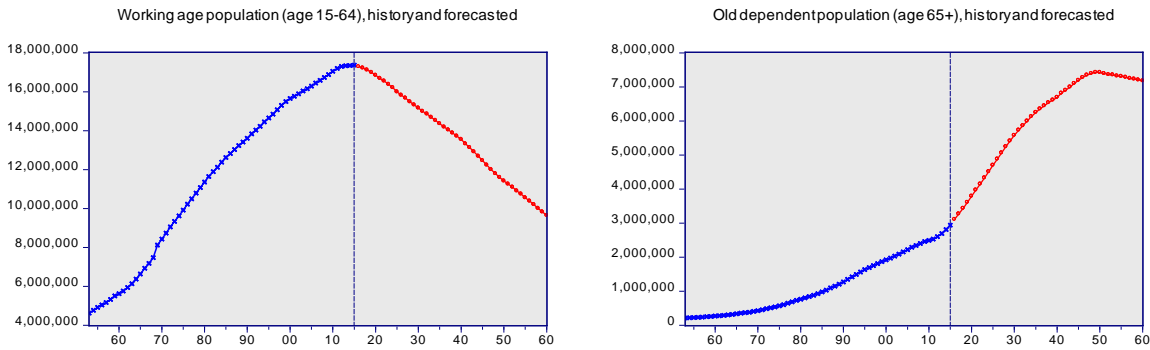

Figure 2. Population in Taiwan, history and projection (1955-2060).

Source: Ministry of Interior (Taiwan) for data before 2016; National Development Council (Taiwan) for population projection beyond 2016.

persons aged 65 and up, has increased in the past decades. At the meanwhile, the size of young dependent population, defined as persons age 14 and less, has declined consistently in the past decades. These scenarios of demographic projections suggest that Taiwan would inevitably experience an unprecedented socio-economic challenge arising from population aging.

The increasing old-age dependency ratio has drawn the public's concern regarding the capability of the pension system to fulfill its commitment in the future. Furthermore, population aging results in a phenomenon that there are less people working and paying income taxes, whereas there are relative more elder people claiming pension and other social welfare benefit. It is worrisome that it 
might be inevitable for the current and future shrinking workforce to pay more tax and pension contribution to support the increasing welfare needs of the elderly. This inter-generational transfer could generate disincentives effects to workers and investors that works together with the shrinking labor supply can lead to a fall in economic growth. This dim prospect of economic growth leads to the concern on sustainability of public finance and pension system. There is a surge in Taiwan that claims a reform on the pension system. The general belief is that a pension reform, by proposing a cut on retirees' benefit or a raise in the contribution of current workforce, would enhance the sustainability of the pension system and promote the welfare of the future working generations.

This paper aims to investigate the impact of population aging on the macroeconomy and explore the welfare effect of pension reform in Taiwan. Given the demographic transition in Taiwan, this paper develops an overlapping generation (OLG) model to explore the effects. With the OLG model at hand, this paper first obtains simulated impact of population aging on the economy and set the simulated "Do-Nothing" policy as the baseline. This paper then obtains scenarios from alternative pension policy reform schemas and compares the results with that of the baseline model to draw conclusions.

Section 2 of this paper reviews literatures related to current study. Section 3 develops the theoretical model used for this study. Section 4 reports the results of model calibration and illustrates the scenarios of various simulation experiments. Sections 5 sums up major finding of this study and draws policy conclusions based on simulation results.

\section{Literature Reviews}

The use of overlapping generation (OLG) model in macroeconomic study was inspired by the seminal works of Samuelson [2] and Diamond [3]. It is Auerbach and Kotlikoff [1] which popularized the use of OLG models in the study of public finance. De La Croix and Michel [4] offered a comprehensive introduction to the setup of the baseline OLG model and provided informative discussions on the application of OLG model to various extensive studies.

The key tenet of the OLG model is the life-cycle income-leisure decision of the representative households, which permits the model to project the accumulation and transfer of wealth, as well as the impacts of policy changes, over time and across generations. The original OLG model introduced by Samuelson [2] and Diamond [3] had only two generations, the young and the old; recent literature has extended the analysis to include 60 to 100 generations (e.g. Heer and Maußner [5]; Muto et al. [6]; Rausch and Rutherford [7]) to study the complex issues involved in the aging economy.

This review discusses the use of OLG model in the study of aging economic issues in general and pension reform with its welfare implication in particular. The canonical work of Samuelson [2] introduced an overlapping generation (OLG) model with life cycle consumption and pay-as-you-go (PAYG) pension system. Diamond [3] extended Samuelson's model and introduced production 
and endogenous interest rate into the model. Thereafter, various extensive literatures with finite life-time agents leaving no bequests have been incorporated into the OLG model. Barro [8] introduced bequest motive and incorporated it into the utility function of the agents in the OLG model. He introduced infinite time horizon into the OLG model and concluded that government debt or social security had no real effects on the economy. Barro's conclusion provoked feverous debates on the role of public policy and pensions in an aging economy. It is argued that a finite life-time OLG model captures better life-cycle behavior than infinite-horizon models. Various extension of OLG models were developed later to handle funded versus unfunded social security pensions, pension reform in an aging economy.

Several authors have contributed to our understanding of using OLG model in the study of aging economy. Kotlikoff [9] presented a review of the present and future of Auerbach and Kotlikoff [1] model. Weil [10] introduced the theoretical development of the OLG model since it was introduced 50 years ago and made a thorough review of issues involved in the OLG model. Rasmussen and Rutherford ([11] [12]) developed computable general equilibrium model to investigate the effect of demographic dynamics on the macroeconomy.

Hviding and Mérette [13] used OLG model to investigate the macroeconomic impact of possible pension reform strategies for seven aging OECD countries. They simulated various reform schemas, including a reduction in the level of pensions, phased abolition of PAYG schemes and general fiscal consolidation, and concluded that any measure that promotes national saving rate can yield higher future GDP levels, but the positive effect on GDP is not enough to offset the effects of ageing. Furthermore, a rise in the retirement age has larger effects, but it implies significant loss of leisure time. In an investigation of aging effects using OLG model, Shimasawa [14] found that a consolidated pension and fiscal reform can promote human capital accumulation and thus accelerate economic growth. Oksanen [15] studied the saving behavior in an economy with permanently declined fertility and increasing longevity. He argued that this demographic development changes the economy's age structure permanently and it is the public pension system that helps to smooth consumption over a lifetime of working and retirement. He used a simple OLG model to simulate the effect of population ageing on the capital to income ratio, the saving ratio and the pension system. The conclusion is that population aging is positively correlated with capital-income ratio and the saving rate. It also showed that moving from a pure PAYG pension system to partial funding of mandatory pensions has positive impact on saving and has implications for intergenerational equity.

In summary, the prime question in the investigation of effects of demographic aging on the economy is "Does population aging affect the economy? If so, how could it happen?" The OLG model has been applied intensively in the search for answers to that prime question. Usually, it is used to explore the impacts of demographic aging on economic growth, on saving and investment, on factor and financial markets, and on the sustainability of public finance and pension sys- 
tem, etc. (e.g. see De La Croix and Michel [4] for introduction). However, not much of the existing study investigates the welfare effect of pension reforms on the aging economy using OLG model. The paper aims to bridge this gap by incorporating exogenous aging transition into an OLG model setting and uses it to investigate the welfare effects of pension reform.

\section{The Model}

The current paper presents an extended dynamic overlapping generation (OLG) model that allow us to analyze the effect of population aging on saving, capital formation and economic growth.

There are four sectors in the economy: households, firms, the government and a pay-as-you-go (PAYG) pension system. There is a representative individual for each generation in the households sector. Each individual has a fixed life time up to age 85 . Each individual with age less than 20 is nurtured by his/her parents and receives education. The individual starts working at age 21 and retires at age 65. Each individual earns wage income and build up savings for old age. The representative agent maximizes his/her intertemporal utility function with consumption. Firms maximize profits. The government collects taxes and social security contributions and runs a balanced budget. The model is a one-country closed economy model, where both the goods market and factor markets are assumed to be perfectly competitive.

A period, $t$, in the model corresponds to one year. At each time period, a new generation of households is born. This models considers only the working and retired generations. Newborns have a real life age of 21 , corresponding to age 1 in the model, denoted by $s=1$. All generations retire at age 65 and lives up to a maximum age of 80 . At each time period there are 60 different generations coexist. At $t$, all agents of age $s$ survive until age $s+1$ with probability $\phi_{s}$, where $\phi_{0}=1$ and $\phi_{J}=0, J=0,1, \cdots, 60$. This paper uses the officially published survival probability of Taiwan estimated by the Statistical Department of Ministry of Interior (Taiwan).

\subsection{Demographic Transition}

Let $N_{t}^{s}$ be the number of agents of age $s$ at $t$. This paper assumes that population grows at the exogenous rate $n=1.1 \%$ until year 2030 and the population growth rate is then assumed to drop by $-0.01 \%$ per annum thereafter. The year 2010 corresponds to $t=0$ and we assume that the economy is in a steady state at $t=0$. The number of population at time $t$ is given by

$$
N_{t}=\sum_{s=1}^{60} \phi_{t}^{s}\left(1+n_{t-1}\right) N_{t-1}^{s}
$$

where $\phi_{t}^{s}$ is the survival probability of generation $s$ at time $t, N_{t}$ is the aggregate population at time $t$.

\subsection{Households Sector}

Each household comprises one representative worker. Households maximize in- 
tertemporal utility at the beginning of age 1 in period $t$.

$$
\operatorname{Max} \sum_{s=1}^{J} \beta^{s-1}\left(\prod_{j=1}^{s} \phi_{t+j-1, j-1}\right) u\left(c_{t+s-1}^{s}, l_{t+s-1}^{s}\right)
$$

The instantaneous utility $u(c, I)$ is a function of consumption $c$ and labor supply 1 :

$$
u(c, l)=\frac{\left(c^{\gamma}(1-l)^{1-\gamma}\right)^{1-\eta}}{1-\eta}, \quad \eta>0, \gamma \in(0,1), \beta>0
$$

where $u(c, l)$ satisfies the usual concavity requirement; $\beta$ denotes the discount factor, $\gamma$ describes the trade-off between leisure and consumption and $1 / \eta$ is the elasticity of intertemporal substitution.

This model assumes that each individual agent's wage income is commensurate with his lifetime productivity and the life cycle productivity is hump shaped with respect to the individual's working ages. That is, at the early stage of the career, the individual is less experienced and less productive, so that his wage income is low. As working experience increases, the individual accumulates knowledge so that his productivity increases in the middle age of career. At the later age of his career, the individual is getting old and is less agile, less adaptive to new technology, so that his productivity declines. An individual agent's lifetime wage income profile is corresponding to his life cycle productivity.

This paper assumes that an agent's efficiency $e^{s}$ depends on its age, $s \in S \cong\{1,2, \cdots, 60\}$ and uses the reported income tax data in Taiwan to estimate the age-efficiency profile in accordance with the age-earning profile in Taiwan. The life cycle labor efficiency profile is estimated as:

$$
e^{s}=1.1671+0.2973 \times s-0.005023 \times s^{2}
$$

The efficiency of the representative generation is normalized with its efficiency at the beginning of his career (Figure 3 ). ${ }^{2}$ The net wage income of working age population in period $t$ of an $s$-year old is given by

$$
\left(1-\tau_{w}-\tau_{b}\right) w_{t} e^{s} l_{t}^{s}
$$

where $w_{t}$ is the wage rate per efficiency labor unit in period $t ; \tau_{w}$ is the wage income tax rate; $\tau_{b}$ is the workers' pension contributions rate. In Equation (4), the new born generation does not possess any assets at the beginning of age $s=1$, hence $w_{t}^{1}=0$. This paper assumes that the older generations do not have bequest incentive, so that parents do not leave bequests to their heirs. The household with age greater than 1 earns interest income with wealth saved in previous periods. The interest rate on assets is $r_{t}, r_{t} \in \mathbb{R}$. Capital income is taxed at rate

${ }^{2}$ The estimation is based on the data published by the Ministry of Finance (Taiwan) for reported wage income in 2012 income tax declaration. The published data is by gender- and by age-groups only; there is no individual age-income data available. Therefore, to obtain estimated income for each individual age, this paper calculates a sex-weighted income for each age group first and then interpolates the data to get age-specific income for each age. The interpolated age-income series is then normalized with the income at age 20. Finally, the normalized series is used to estimate age-earning profile in Equation (4) which yields the plots in Figure 3. 


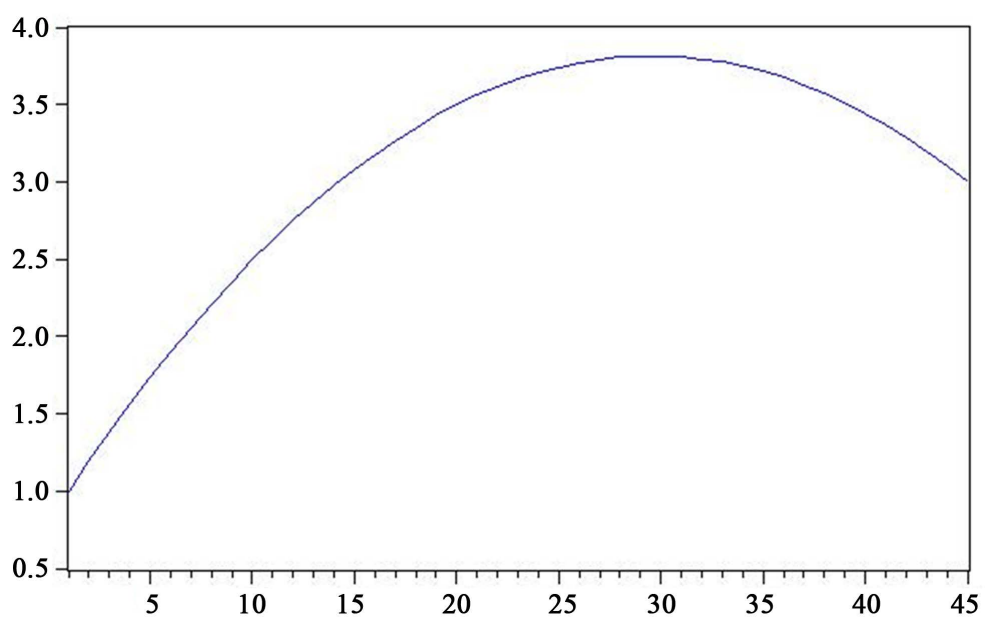

Figure 3. Lifetime age-earning profile of a representative household. Source: Author's own estimation. See Footnote 2 for explanation.

$\tau_{r}$. In addition, households receive lump sum transfers $\operatorname{Tr}_{t}$ from the government. Retired household receives pensions $b_{s}^{j}$. For the working age population, we have $b_{s}=0$ if $s<R$ (where $R=44$, the beginning of retirement age). The budget constraint of an $s$-year old household at time $t$ with wealth $w_{t}$ is:

$$
b_{t}^{s}+\left(1-\tau_{w}-\tau_{b}\right) w_{t} e^{s} l_{t}^{s}+\left[1+\left(1-\tau_{t}\right) r_{t}\right] w_{t}^{s}+T r_{t}=c_{t}^{s}+w_{t+1}^{s+1}
$$

The household's saving is assumed to held in government bonds $\left(d_{t}^{s}\right)$ or lending to the firms for investment $\left(k_{t}^{s}\right)$. Household's saving which is not held in bonds is the source of injection to national capital stock. The amount of bonds held by each household is the average of bonds held; that is, $d_{t}^{s}=\overline{d_{t}}=D_{t} / N_{t}$. For the $s^{\text {th }}$ generation during its working time, its asset which is used in capital formation can be written as:

$$
\begin{aligned}
k_{t}^{s}= & \left(1-\tau_{w}-\tau_{b}\right) w_{t}^{s} e^{s}-\left(1+\tau_{c}\right) c_{t}^{s}-d_{t}^{s} & & \text { for } s=1, \\
k_{t}^{s}= & {\left[1+\left(1-\tau_{r}\right) r_{t}\right] k_{t-1}^{s}+\left(1-\tau_{w}-\tau_{b}\right) w_{t}^{s} e^{s} } & & \\
& -\left(1+\tau_{c}\right) c_{t}^{s}+\left[1+\left(1-\tau_{r}\right) r_{t}\right] d_{t-1}^{s}-d_{t}^{s} & & \text { for } 2 \leq s \leq 44, \\
k_{t}^{s}= & {\left[1+\left(1-\tau_{r}\right) r_{t}\right] k_{t-1}^{s}+b_{t}^{s}-\left(1+\tau_{c}\right) c_{t}^{s} } & & \\
& +\left[1+\left(1-\tau_{r}\right) r_{t}\right] d_{t-1}^{s}-d_{t}^{s} & & \text { for } 45 \leq s<59, \\
k_{t}^{s}= & 0 & & \text { for } s=59
\end{aligned}
$$

\subsection{Firms}

At each $t$, firms produce output, $Y_{t}$ using Cobb-Douglas type constant returns to scale production function:

$$
Y_{t}=A_{t} L_{t}^{1-\alpha} K_{t}^{\alpha}
$$

Productivity $A_{t}$ grows at the exogenous rate $g_{A}$. The firm decides the demand for physical capital and effective labor to maximize profits with given factor prices. The factor prices, wage $\left(w_{t}\right)$ and interest rate $\left(r_{t}\right)$, are determined in the perfect competitive markets. Profit maximization gives rise to the first-order conditions: 


$$
\begin{aligned}
& \frac{\partial Y_{t}}{\partial K_{t}}=r_{t}+\delta=\alpha k_{t}^{\alpha-1} \\
& \frac{\partial Y_{t}}{\partial L_{t}}=w_{t}=(1-\alpha) k_{t}^{\alpha}
\end{aligned}
$$

where $k_{t}=K_{t} / A_{t} L_{t}$ denotes the capital per effective labor in period $t$ and $\delta$ denotes the depreciation rate.

\subsection{The Government Sector}

The government collects two types of income taxes, wage tax and capital tax, to finance its expenditures on government consumption $\left(G_{t}\right)$ and transfers $\left(T_{t}\right)$. The government's tax revenues $\left(T_{t}\right)$ are given by

$$
T_{t}=\tau_{w} w_{t} L_{t}+\tau_{r} r_{t} W_{t}
$$

where $W_{t}$ is aggregate wealth at $t$. Government spending is a constant fraction of output:

$$
G_{t}=\bar{g} Y_{t}
$$

The government finances the deficiencies in general expenditure by issuing new debt to the public. Let $D_{t}$ denotes government bonds outstanding at time $t$. Assume that the government budget is balanced in every period $t$, so that the government budget constraint is give as:

$$
G_{t}+T r_{t}=T_{t}+D_{t}
$$

\subsection{The Pension Sector}

The social security system is a pay-as-you-go system. The pension sector grants a pension to the retirement generations while the pension contribution is collected from the working generations. Pensions are a constant fraction of net labor income:

$$
b_{t}^{s}= \begin{cases}0 & s<R \\ \zeta\left(1-\tau_{w}-\tau_{b}\right) w_{t} & s \geq R\end{cases}
$$

The replacement ratio of net pensions, $\zeta=b_{t} /\left(1-\tau_{w}-\tau_{b}\right) w_{t}$, is assumed to be constant. In this case, the contribution rate $\tau_{b}$ has to adjust in order to balance the social security budget. The budget constraint of the pension sector is that total pension contribution received from period $t-1$ equals to the current periods', period $t$, pension benefit payments.

\subsection{Stationary Equilibrium}

In the stationary equilibrium, individual behavior is consistent with the aggregate behavior of the economy, firms maximize profits, households maximize inter-temporalutility, and factor and goods' markets are in equilibrium. The aggregate variables labor supply $L_{t}$ consumption $C_{t}$ taxes $T_{t}$ capital stock $K_{t}$ and bonds $D_{t}$ are equal to the sum of the individual variables. Aggregate saving is the sum of $K_{t}$ and $D_{t}$ The budget of the social security system as well as the government budget is balanced. 


\section{Model Estimation and Simulation}

Given the model illustrated in previous section, this paper applies the practical data in Taiwan for model estimation and simulation and uses the software package Matlab in the study.

\subsection{Data and Parameterization}

In the OLG model estimation this paper assumes that each household starts his lifetime career at physical age 21 , corresponding to model age $1(s=1)$. All households retire at the mandatory retirement age, which is 65 in Taiwan (corresponding to model generation $s=44$ ), and survive up to age 80 , which is the average life expectancy in Taiwan and corresponds to model age $s=59$. An individual's lifetime wage income is assumed to associate with the bump shaped life cycle efficient as illustrated in Figure 3. Household's intertemporal elasticity of substitution for consumption $(\theta)$ is set at 0.25 as in Auerbach \& Kotlikoff ([1], p. $51)$ and time discount factor $(\beta)$ at 0.97 as in Chang \& Guan ([16], p. 123). The depreciation rate is set to 0.04 that are nearly in line with empirical data in Taiwan. Pension contribution and replacement rate is the average figures based on the current Pay As You Go system in Taiwan. All taxes rates reveal the current effective tax rate and are assumed to be fixed at the 2012 levels. Table 1 reports the parameters values used in the model estimation. This paper uses the survival probabilities for the year 2014 as estimated by the Ministry of Interior (Taiwan). ${ }^{3}$ The survival probabilities decrease with age and are presented in Figure 4.

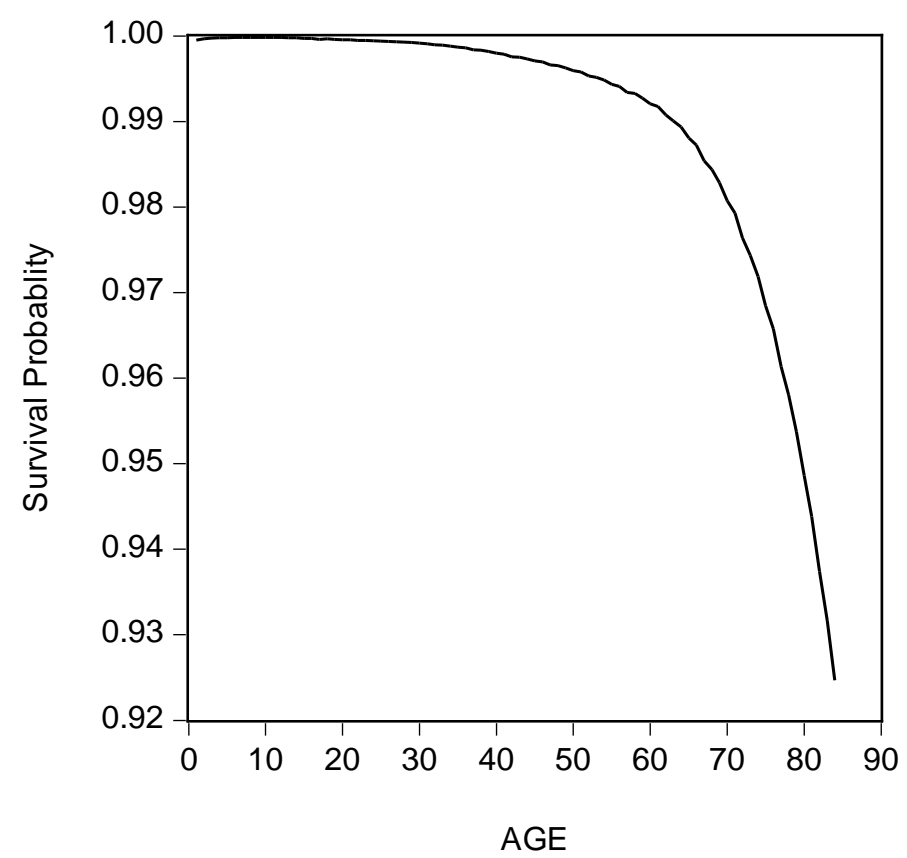

Figure 4. Survival probability by age.

Source: Department of Statistics, Ministry of Interior (Taiwan) (see footnote 3).

${ }^{3}$ The abridged life table of Taiwan is available. 
Table 1. Parameter values setting.

\begin{tabular}{ccc}
\hline$\alpha$ & Capital's share of output & 0.33 \\
$\beta$ & Time discount factor & 0.97 \\
$\delta$ & Depreciate rate & 0.04 \\
$d$ & Technical progress rate & 0.015 \\
$\rho$ & Pension-income replacement ratio & 0.465 \\
$\theta$ & Tax rate on capital income & 0.25 \\
$\tau_{r}$ & Consumption tax rate & 0.14 \\
$\tau_{c}$ & Wage income tax rate & 0.05 \\
$\tau_{w}$ & Worker's public pension contribution rate & 0.135 \\
$\tau_{s}$ & Government's share of public pension premium & 0.13 \\
$k_{s}$ &
\end{tabular}

\subsection{The Role of Technological Progress in Aging Economy}

Given the demographic and macroeconomic scenarios in Taiwan, this paper first investigates the transition path of some macroeconomic variables with the impacts of population aging. It is acknowledged that population aging causes aging of the labor force and reduces the portion of working age population in the economy. It is also recognized that promoting technological progress can mitigate the adverse effect of shrinking working age population on aggregate output. Therefore, this study first compares the macroeconomic outcomes of the economy with/without technological progress. Figure 5 illustrates the scenarios of selected key macroeconomic variables under these alternative simulations.

In Figure 5, the dashed lines indicate the case where the rate of technological progress is zero $(g=0)$ and the solid lines signify the case with a $1.5 \%$ constant annual technological growth $(g=0.015)$. Comparing the performance of GDP in these two simulations (panel A), it is obvious that, given the presence of population aging, the economy will experience output decline eventually, no matter the economy has technological progress or not. However, the timing of output decline will come approximately 70 years early in the no technological progress case, comparing to that of the alternative case. Moreover, the peaked output level in the no technological progress case (right scale) is only about $1 / 10$ of the peaked value in the alternative case (left scale).

In addition to the output effect, the generational welfare effects of population aging can be observed from two other aspects of the economy, namely, the consumption welfare effect and income-class welfare difference. The generational consumption welfare can be observed by comparing the consumption levels of the current and future generations. In panel B, the scenarios of per capita consumption with no technological progress indicate that the level of consumption per capita starts to decline approximately 20 years from the initial steady state. In the long-run, the future generations have a lower per capita consumption than that of the current generation. On the contrary, the scenarios of the alternative case indicate that consumption welfare per capita increase all the way, so that future generations enjoy a better material life than the current generation. 


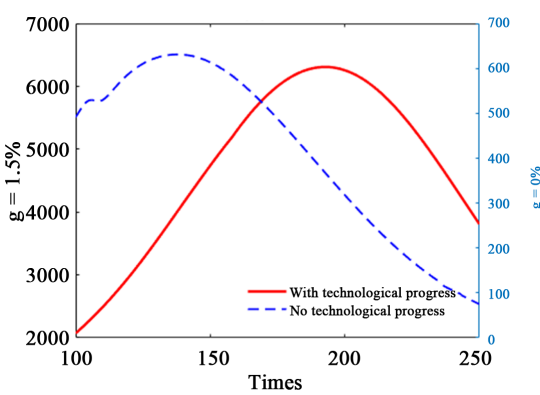

(a)

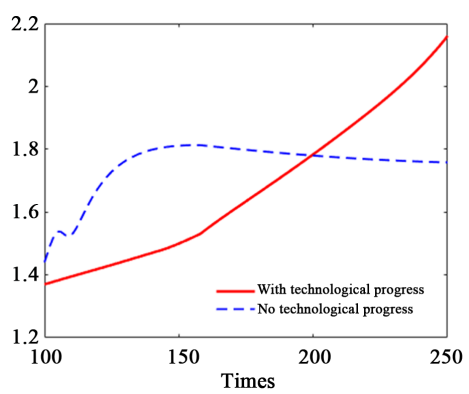

(c)

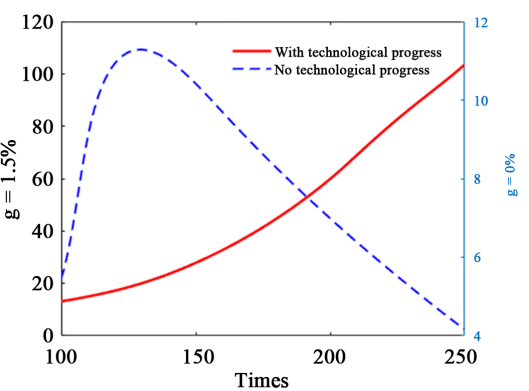

(b)

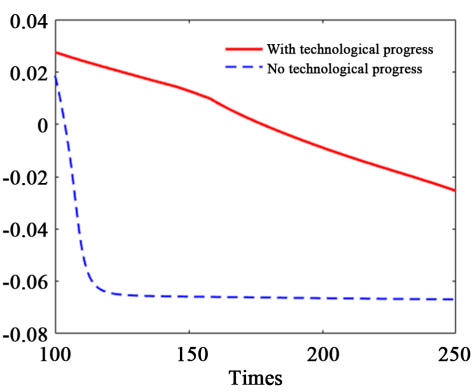

(d)

Figure 5. The role of technological progress in an aging economy.

Source: Model simulation results prepared by the author. (a) GDP; (b) Per capita consumption; (c) Wage Rate; (d) Interest rate.

Further, per capita consumption in the alternative case is far more above that of no technological advancement case. In conclusion, an aging economy without technological progress harms consumption welfare of future generations.

The income-class welfare can be observed with the variations in factor prices due to population aging. "Class" in this study implies the categorization of income earners; that is, it represents the distinction between wage income and capital income earners. Since most of the saving in the economy comes from the middle-age or old-age households, aggregate saving or assets stock will increase in line with the transition of population aging. However, the transition toward aging economy is accompanied with a shrinking working age population. As a result, capital in the aging economy is a relative abundant factor whereas labor is a relative scare resource. The factor markets dynamics associate with the transition of population aging will change the relative factor prices and generate a more favorable income condition for the laborers. The simulation results from this study confirm this common belief.

The simulation results indicate that population aging creates advantageous effect for the wage earners and disadvantageous effect for the interest earners. Panel $\mathrm{C}$ indicates that, in the case with $\mathrm{g}=0$, the wage rate will increase in the first instance, rising with the phase of population aging, and then stagnate approximately 50 years from the initial steady state. There is a shocking precipitation of the interest rate in the first years of aging in the no technological progress case. The capital return stays negative and becomes trapped thereafter (panel D). It seems that population aging yields an advantageous income condition for the 
laborers against that of the capital owners. In the case with technological progress the wage rate does not stagnate at all. Wage rate keeps rising even that the GDP has declined. Capital in the technological advancement case reveals a long-run trend in falling rate of return. Although capital returns never stagnate in this latter case, population aging is harmful to future generations who own capital. In conclusion, the simulation experiments in this study confirm that population aging leads to an advantageous welfare condition for the wage earners and disadvantageous condition for the capital owners; it also harms future generations who own assets.

\subsection{Pension Reforms and Its Macroeconomic and Welfare Effects}

Population aging alters age composition of the economy with a decline in the proportion of young people to retirees. This has substantial impacts on the current pay-as-you-go (PAYG) pension system. People fear that the pension system may go into bankruptcy in the future. Even if the system keeps working, a higher ratio of pensioners to employees necessitates higher tax or premium contributions to maintain the sustainability of the fiscal and pension systems. This puts burdens on the current and future working generation. Therefore, people urge the government to take action in reforming current PAYG pension system. Possible solution proposals to enhance the sustainability of the pension system include increasing premium contribution, reducing pension benefit, postponing the eligible age for pension benefit, and/or combination of these measures.

In light of conventional wisdom, this paper analyzes the effects of four reforms in the pension system that is proposed enhance the sustainability of the pension system: (a) an increase in the contribution by $15 \%$; (b) a reduction in the pension benefit by cutting $15 \%$ of the replacement ratio; (c) a mild extension of mandatory retirement age by 1 year; and (d) a more progressive reform in cutting pension benefit and postponing mandatory retirement, a combination of (b) and (c). This paper uses the simulation outcome of model with a constant rate of technological progress $(g=0.015)$ as the baseline for reform effect comparisons. The effects are compared by examining the scenarios in nine variables, namely, GDP, per capita consumption, pension per capita, aggregate save rate, pension benefit to GDP ratio, average lifetime utility, wage rate, interest rate, and government budget surplus/deficit status.

This paper uses GDP and aggregate saving rate to capture the reform effect on the macroeconomy and uses wage rate and interest rate to mirror the effects on the factor market. In order to examine the welfare consequence of pension reform, this paper uses pension per capita and pension to GDP ratio to monitor the reform outcomes and uses consumption per capita to index the effect on consumption welfare. People are concerned about the fiscal consequence of pension reform. Therefore, this paper uses government budget surplus/deficit to pick up the reform effect on fiscal condition. Finally, this study uses the lifetime utility to mirror the overall welfare effect of pension reform on the representative household. Figures 6-9 illustrate the simulated results of each reform program respectively. 


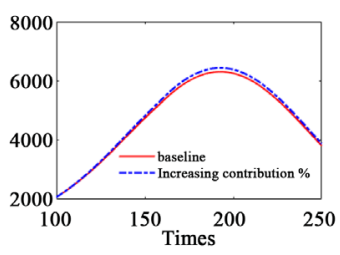

(a)

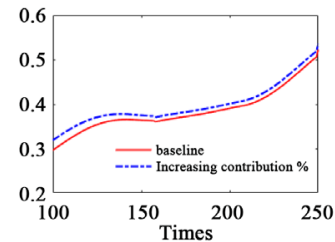

(d)

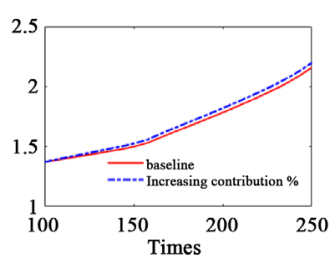

(g)

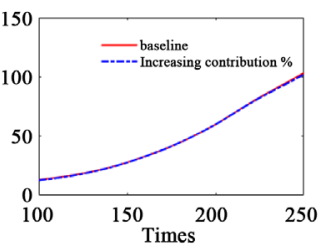

(b)

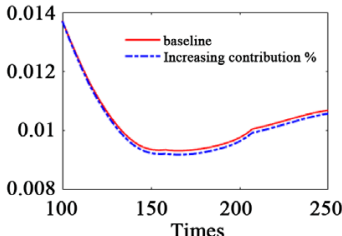

(e)

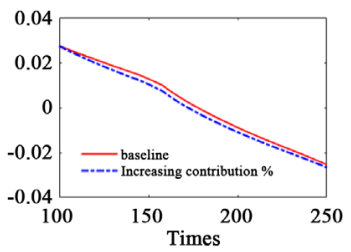

(h)

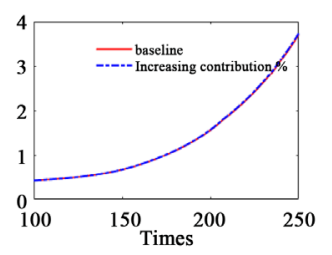

(c)

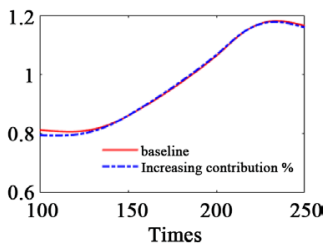

(f)

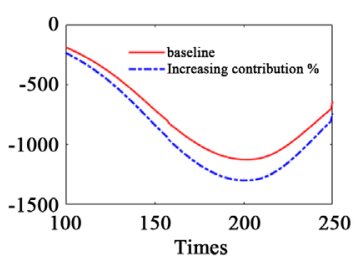

(i)

Figure 6. Pension reform case (a): An increase in pension premium contribution. Sources: Model simulation results prepared by the author. (a) GDP; (b) Per capita consumption; (c) Pension per capita; (d) Saving rate; (e) Pension benefit/GDP; (f) Lifetime utility; (g) Wage rate; (h) Interest rate; (i) K/L ratio.

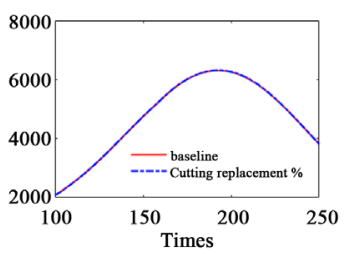

(a)

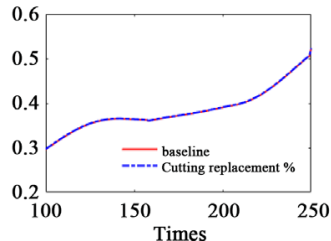

(d)

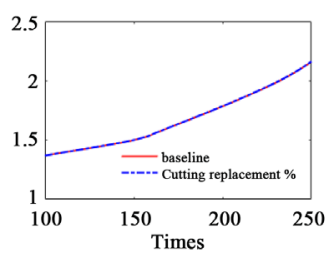

(g)

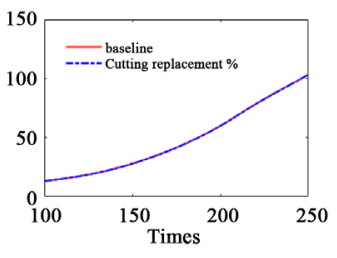

(b)

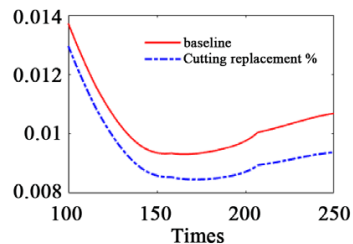

(e)

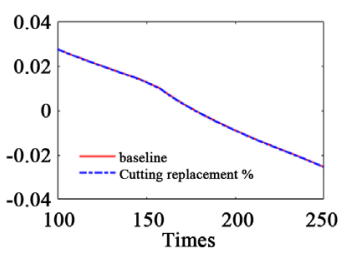

(h)

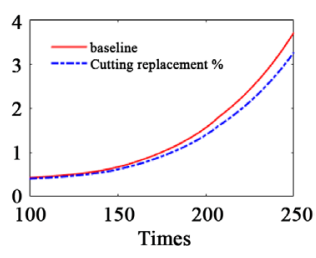

(c)

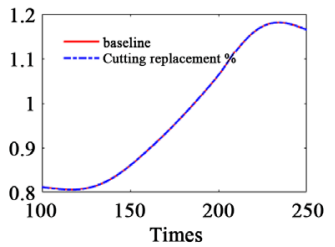

(f)

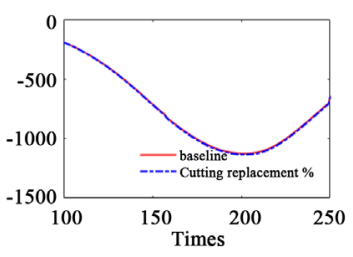

(i)

Figure 7. Pension reform case (b): Cutting replacement ratio. Source: Model simulation results prepared by the author. (a) GDP; (b) Per capita consumption; (c) Pension per capita; (d) Saving rate; (e) Pension benefit/GDP; (f) Lifetime utility; (g) Wage rate; (h) Interest rate; (i) K/L ratio. 


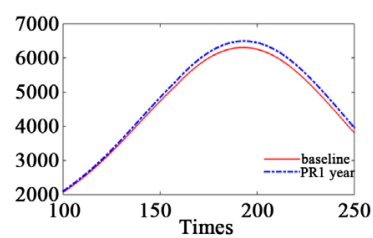

(a)

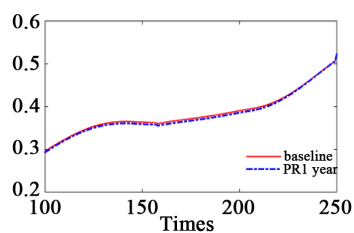

(d)

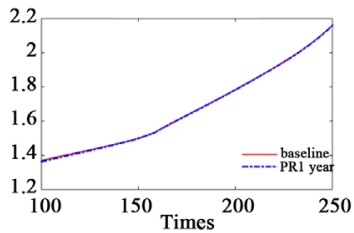

(g)

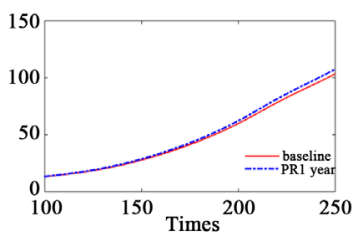

(b)

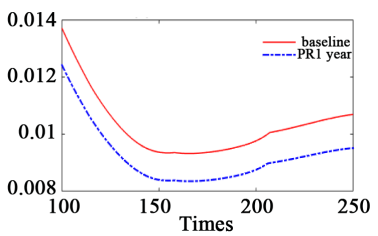

(e)

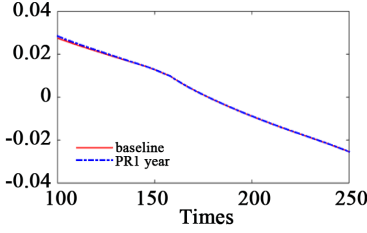

(h)

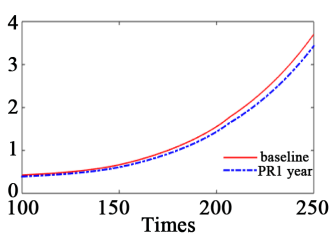

(c)

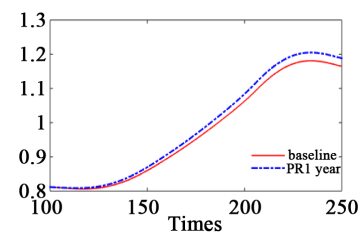

(f)

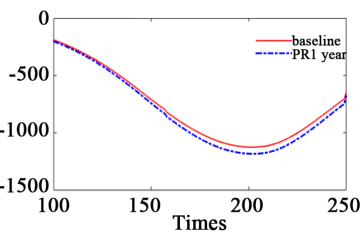

(i)

Figure 8. Pension reform case (c): Extending mandatory retirement age. Source: Model simulation results prepared by the author. (a) GDP; (b) Per capita consumption; (c) Pension per capita; (d) Saving rate; (e) Pension benefit/GDP; (f) Lifetime utility; (g) Wage rate; (h) Interest rate; (i) K/L ratio.

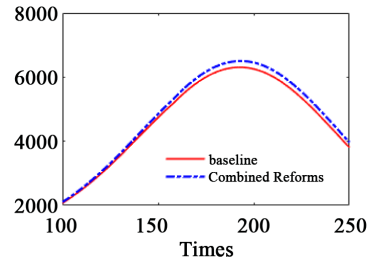

(a)

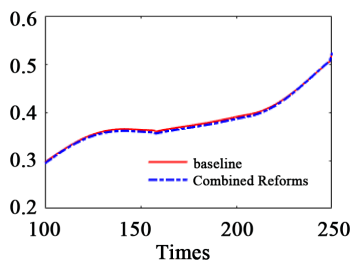

(d)

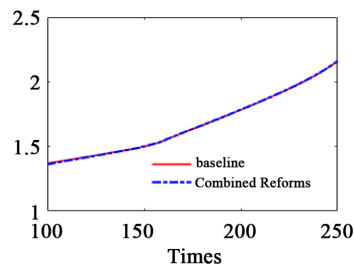

(g)

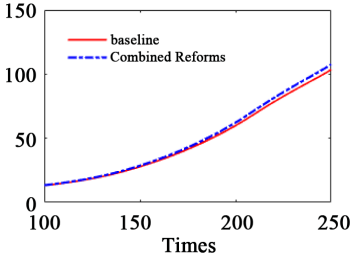

(b)

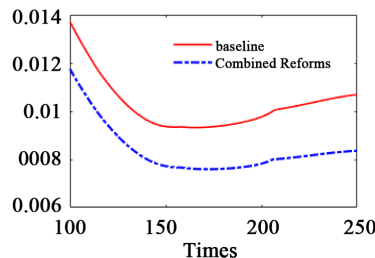

(e)

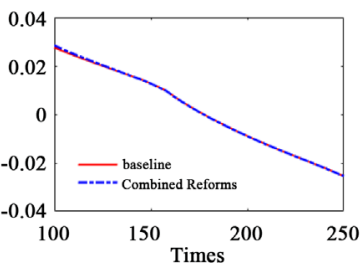

(h)

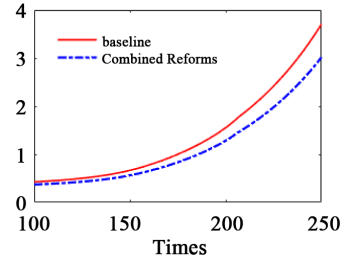

(c)

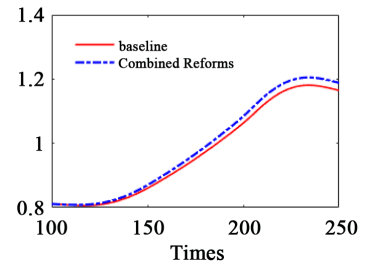

(f)

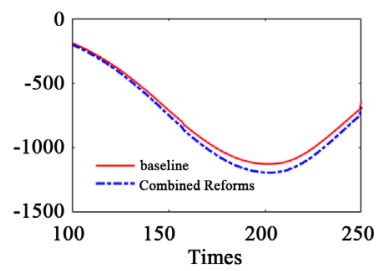

(i)

Figure 9. Pension reform case (d): A combined reform of case (b) \& case (c). Source: Model simulation results prepared by the author. (a) GDP; (b) Per capita consumption; (c) Pension per capita; (d) Saving rate; (e) Pension benefit/GDP; (f) Lifetime utility; (g) Wage rate; (h) Interest rate; (i) $\mathrm{K} / \mathrm{L}$ ratio. 
Figure 6 represents the scenarios of the reform package with a 15\% increase in the contribution ratio (case (a)). The scenarios of the baseline model are illustrated with solid lines in the graphs. It is noticed that this reform reduces the net wage income of the households, so that it induces the incentive for precautionary saving. As a result, saving rate increases. The increased saving injects to new capital stock so that K/L ratio increases and GDP increases. The increase in capital stock has the effect of reducing capital return in the capital market. In the labor market, the labor cost has risen due to risen pension contribution. Although GDP has risen in the economy, per capita consumption does not change because saving rate increased. For the pension benefit in the economy, per capita pension revenue has no obvious change whereas the overall pension to GDP ratio has reduced, probably due to the rise in GDP. The government budget deficit has worsened because, under current pension regime, the government is responsible for $60 \%$ of the pension contribution. For the lifetime utility of the households, this reform debases the utility of the current generations whereas does not impact much on the utility of future generations.

The second policy experiment, case (b), is cutting the retirees' pension benefit by $15 \%$. Currently Taiwan has multiple pension programs for the public servants, military service men, the laborers, and the farmers respectively. A consolidation effort to integrate these multiple pension programs into a single national pension program is on the way to the legislative process. At this moment, the effective average replacement ratio is 0.465 . This paper performs an experiment on a cut of this average replacement ratio to 0.395 . Figure 7 illustrates the simulated results of this change. This reform measure does not change households' net wage income, so that the working-saving decision of the households has not been affected. As a result, most of the macroeconomic variables do not change with the change in this reform measure. This reform package neither affects the government budgetary condition. However, the pension benefit one the microand macro-level has been changed. Per capita pension benefit does not show significant change for the current generations; however, pension benefit per capita for the future generation has worsened. On the macro-level, pension benefit to GDP ratio has lowered and this ratio is much lower for the future generations. The overall lifetime utility of the household does not change much with the change in this pension policy.

The third experiment, case (c), is on the postponement of the eligibility for claiming pension benefit. Current pension arrangement in Taiwan sets age 65 as the mandatory retirement age. This study considers an extension of this mandatory retirement age by 1 year; that is, from 65 to 66 . This reform has a direct effect on labor supply and a time effect on the delayed payment of pension benefit by the pension system. With delayed retirement, labor supply increases which contributes to GDP growth. The increased GDP induces an increase in per capita consumption. The future generations enjoy more national income and consumption per capita than the current generations do. This reform also causes a slightly reduction in the saving rate but does not result in obvious effect on the 
factor market. The government budgetary deficit has worsened, because postponed retirement implies that the government is responsible for the additional due share in the pension contribution. This reform has a more noticeable effect in reducing the pension to GDP ratio and pension benefit per capita. Even though the reform measure causes a reduction in per capita pension, it still yields a noticeable increase on the overall lifetime utility for the future generations (Figure 8).

The last experiment, case (d), is a combination of cutting pension benefit and postponing mandatory retirement by 1 year (Figure 9). The simulated scenarios are basically similar to that of case (c), except that the effects on pension per capita and pension benefit to GDP are more prominent in this case. Moreover, this reform also improves the lifetime utility of the future generations as in case (c).

In summary, the effect of pension reform operates through its impacts on households' lifetime income and consumption. The overall effect of the reform package depends on how much it impacts on the households' working-saving decision and how these impacts transmitted to the other sectors. Of the four reform experiments discussed in this paper, the increase in the contribution ratio has the most significant ripple effect to the economy; cutting pension benefit by reducing the replacement ratio has the least adverse effect on government budgetary condition; extending the mandatory retirement age has the least distortion effect on the factor market; increasing pension contribution encourages saving ratio, promote capital formation and future GDP.

For the consumption welfare effect, neither raising contribution nor cutting replacement ratio has significant effect on altering generational consumption welfare. However, postponing mandatory retirement improves consumption welfare of the future generation. For the pension welfare, increasing pension contribution has the least adverse impact on pension to GDP ratio and also has the least detrimental impact on future generations' per capita pension. For the reform effect on the lifetime utility, cutting replacement ratio has no observable effect on it; increasing pension contribution worsens the lifetime utility of current generation without any improvement on future generations' utility; however, postponing mandatory retirement age does not harm much of the current generation whereas it has a gradual improvement effect on future generations' life time utility.

\section{Conclusions}

This paper presents a four-sector, multi-generation overlapping generation (OLG) model to explore the effects of pension reform in an aging economy. The four sectors of the model are the households sector, the sector of firms, the public sector, and a pay-as-you-go (PAYG) pension system. The economic data and institutional setting of Taiwan are used in this study.

Many people concern about the effect of population aging on economic growth, the sustainability of public and private transfer systems, and generational welfare impacts. This paper uses multigenerational OLG model to investigate 
the welfare effects of pension reform in an aging economy and investigates the effects of various reform measures aiming to enhance the sustainability of the pension system. The reform measures considered in this paper are: an increase in pension contribution, a reduction in pension benefit, postponing mandatory retirement age, and a combination of extending retirement age and reducing pension benefit. Policy simulation results are investigated with nine variables representing economic growth, saving, factor market, consumption welfare, pension benefit, government budgetary position, and lifetime utility. Although all reform measures aim to ensure the long-term sustainability of the pension system, alternative reform scheme yields impacts on different aspects of the economy. For example, increase in contribution ratio can improve future GDP whereas reducing replacement ratio cannot; increase in pension contribution worsens government budgetary condition whereas reducing replacement ratio does not; increase in pension contribution reduces lifetime utility of the current generation without adding benefit to the utility of future generation whereas extending mandatory retirement age can improve future generations' utility without harming much of the current generations' utility. From the welfare prospective, the authority has to be more cautious in acknowledging the ripple effect of the pension reform policy and its implications on generational welfare.

This paper applies OLG model to investigate the welfare effect of pension reform in the aging economy of Taiwan. Policy simulations in this paper have yielded several meaningful conclusions and the results provide some reference answers to the practical socio-economic concerns in Taiwan. However, the conclusions of this paper are drawn based on certain theoretical assumptions. For example, this paper assumes that all households are homogenous in productivity and does not consider heterogeneity in skill and human capital formation. Furthermore, the current paper assumes that households do not have bequest motive so that everyone consumes up all his lifetime income from works and saving. This paper does not take care of the possible impacts of bequest and human capital formation on generational welfare in the aging economy. Future works on pension reform study can specify human capital and bequest motive in the households' utility function so that the results can represent more represent real world situations.

\section{References}

[1] Auerbach, A. and Kotlikoff, L. (1987) Dynamic Fiscal Policy. Cambridge University Press, Cambridge.

[2] Samuelson, P.A. (1958) An Exact Consumption-Loan Model of Interest with Or without the Social Contrivance of Money. Journal of Political Economy, 66, 467482. https://doi.org/10.1086/258100

[3] Diamond, P.A. (1965) National Debt in a Neoclassical Growth Model. American Economic Review, 55, 1126-1150.

[4] De La Croix, D. and Michel, P. (2002) A Theory of Economic Growth: Dynamics and Policy in Overlapping Generations. Cambridge University Press, Cambridge. https://doi.org/10.1017/CBO9780511606434 
[5] Heer, B. and Maußner, A. (2009) Dynamic General Equilibrium Modeling: Computational Methods and Applications. 2nd Edition, Springer, Berlin; New York. https://doi.org/10.1007/978-3-540-85685-6

[6] Muto, I., Oda, T. and Sudo, N. (2016) Macroeconomic Impact of Population Aging in Japan: A Perspective from an Overlapping Generations Model. IMF Economic Review, 64, 408-442. https://doi.org/10.1057/imfer.2016.6

[7] Rausch, S. and Rutherford, T.F. (2010) Computation of Equilibria in OLG Models with Many Heterogeneous Households. Computational Economics, 36,171-189. https://doi.org/10.1007/s10614-010-9229-8

[8] Barro, R. (1974) Are Government Bonds Net Wealth? Journal of Political Economy, 82, 1095-1117. https://doi.org/10.1086/260266

[9] Kotlikof, L. (2000) The A-K OLG Model: Its Past Present and Future. In: Glenn, W., Jensen, S., Pedersen, L. and Rutherford, T., Eds., Using Dynamic General Equilibrium Models for Policy Analysis, North-Holland, Amsterdam, 13-52.

[10] Weil, P. (2008) Overlapping Generations: The First Jubilee. Journal of Economic Perspectives, 22, 115-134. https://doi.org/10.1257/jep.22.4.115

[11] Rasmussen, T.N. and Rutherford, T.F. (2004) Modeling Overlapping Generations in a Complementarity Format. Journal of Economic Dynamics and Control, 28, 13831409. https://doi.org/10.1016/S0165-1889(03)00117-9

[12] Rasmussen, T.N. and Rutherford, T.F. (2010) Computation of Equilibria in OLG Models with Many Heterogeneous Households. Computational Economics, 36, 171-189.

[13] Hviding, K. and Mérette, M. (1998) Macroeconomic Effects of Pension Reforms in the Context of Ageing Populations: Overlapping Generations Model Simulations for Seven OECD Countries. OECD Economics Department Working Papers, No. 201, OECD Publishing. https://www.oecd.org/fr/japon/35245683.pdf

[14] Shimasawa, M. (2007) Population Ageing, Policy Reforms and Economic Growth in Japan: A Computable OLG Model with endogenous Growth Mechanism. Economics Bulletin, 3, 1-11.

[15] Oksanen, H. (2009) Saving in an Ageing Society with Public Pensions: Implications from Lifecycle Analysis. No. 370, European Economy, Economic Papers from Directorate General Economic and Monetary Affairs, European Commission, $31 \mathrm{p}$. http://ec.europa.eu/economy_finance/publications/pages/publication14320_en.pdf

[16] Chang, Y. and Guan, D. (2005) An Empirical Study on Total Factor Productivity and Economic Growth in Taiwan. Socioeconomic Law and Institution Review, 36, 111-154. 
Submit or recommend next manuscript to SCIRP and we will provide best service for you:

Accepting pre-submission inquiries through Email, Facebook, LinkedIn, Twitter, etc. A wide selection of journals (inclusive of 9 subjects, more than 200 journals)

Providing 24-hour high-quality service

User-friendly online submission system

Fair and swift peer-review system

Efficient typesetting and proofreading procedure

Display of the result of downloads and visits, as well as the number of cited articles Maximum dissemination of your research work

Submit your manuscript at: http://papersubmission.scirp.org/

Or contact ajibm@scirp.org 